\title{
LIPIDOID IRON OXIDE NANOPARTICLES ARE A PLATFORM FOR NUCLEIC ACID DELIVERY TO THE LIVER
}

Uvarova $\mathrm{Vl}^{1,3} \otimes$, Nizamov TR ${ }^{1}$, Abakumov MA¹, Vodopyanov SS ${ }^{1}$, Abakumova TO², Saltykova IV³, Mogilnikov PS ${ }^{4}$,

Shchetinin IV4, Majouga $A G^{1,5}$

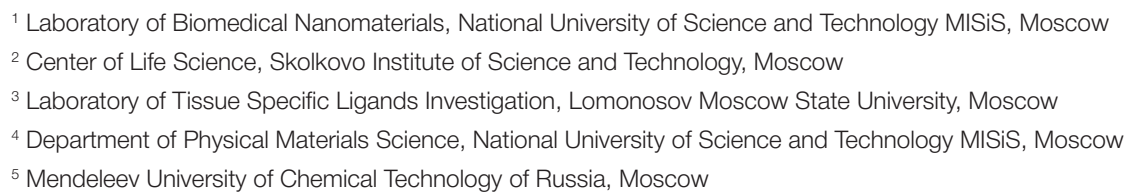

Targeted delivery of antisense drugs is a promising technology which can provide a platform for the development of highly effective therapeuticals against a broad range of diseases. Insufficient stability of RNA in biological media coupled with hydrophilicity that prevents the molecule from penetrating cell membranes considerably limit RNA application in clinical practice. The aim of this work was to design a system for antisense drug delivery to liver hepatocytes using lipidoid magnetic nanoparticles (LNP). Nanocubes (NC) with average sizes of 16 and $27 \mathrm{~nm}$ were synthesized through decomposition of iron (III) oleate under high temperature conditions and functionalized with a cationic lipidoid C12-200. Magnetic NC demonstrated good MR-contrasting properties. Biodistribution of LNP was studied in vivo in BALB/c mice using the MR scanner. Additionally, liver sections obtained from the mice were subjected to histological examination. Nanoparticles of smaller size did not have a cytotoxic effect on HepG2 and Huh7 cell lines, whereas for larger NC, IC ${ }_{50}$ was $21.5 \mu \mathrm{g} / \mathrm{ml}$ and $126 \mu \mathrm{g} / \mathrm{ml}$ for HepG2 and Huh7 cells, respectively. Smaller particles tended to accumulate in hepatocytes. Bigger NC mainly accumulated in the spleen but also ended up in liver macrophages. This fact can be explained by a bigger hydrodynamic size of nanoparticles with a bigger magnetic core. Particles with smaller cores are a more effective platform for the delivery of antisense drugs to hepatocytes.

Keywords: magnetic nanoparticles, MRI, lipids, targeted delivery

Funding: the study was funded by the Ministry of Science and Higher Education of the Russian Federation. Project 14.578.21.0201 (ID RFMEFI57816X0201).

Correspondence should be addressed: Victoria I. Uvarova

Leninsky 4, Moscow, 119049; uvarova_viktoriya@bk.ru

Received: 26.06.2018 Accepted: 25.08.2018

DOI: $10.24075 / \mathrm{brsmu} .2018 .080$

\section{ЛИПИДОПОДОБНЫЕ НАНОЧАСТИЦЫ ОКСИДА ЖЕЛЕЗА КАК ПЛАТФОРМА ДЛЯ ДОСТАВКИ НУКЛЕИНОВЫХ КИСЛОТ В ПЕЧЕНЬ}

\author{
В. И. Уварова ${ }^{1,3}$, Т. Р. Низамов ${ }^{1}$, М. А. Абакумов ${ }^{1}$, С. С. Водопьянов ${ }^{1}$, Т. О. Абакумова И. В. Салтыкова $^{3}$ \\ П. С. Могильников ${ }^{4}$, И. В. Щетинин ${ }^{4}$, А. Г. Мажуга ${ }^{1,5}$ \\ Лаборатория биомедицинских наноматериалов, Национальный исследовательский технологический университет «МИСиС», Москва \\ 2 Центр наук о жизни, Сколковский институт науки и технологий, Москва \\ з Лаборатория тканеспецифических лигандов, Московский государственный университет имени М. В. Ломоносова, Москва \\ ${ }^{4}$ Кафедра физического материаловедения, Национальный исследовательский технологический университет «МИСиС», Москва \\ ${ }^{5}$ Российский химико-технологический университет имени Д. И. Менделеева, Москва
}

Адресная доставка антисмысловых препаратов является перспективной технологией, на основе которой возможна разработка высокоэффективных лекарственных средств для терапии широкого спектра заболеваний. Однако недостаточная стабильность РНК в биологических средах и гидрофильность, ограничивающая проникновение через клеточные мембраны, существенно сужают их использование в клинической практике. Целью исследования была разработка средств доставки антисмысловых препаратов в гепатоциты печени с помощью липидоподобных магнитных наночастиц (ЛНЧ). Кубические магнитные наночастицы (НЧ) со средними размерами 16 и 27 нм синтезировали методом высокотемпературного разложения прекурсора - олеата железа (III) и химически модифицировали формуляцией, включающей катионный липидоид С12-200. Магнитные НЧ обладают хорошими МРТ-контрастными свойствами, биораспределение ЛНЧ исследовали in vivo на линейных мышах BALB/c c помощью MP-томографра. C этой же целью провели последующее гистологическое исследование срезов печени. Наночастицы меньшего размера не продемонстрировали цитотоксического действия по отношению к клеточным линиям НерG2 и Huh7, a для H4

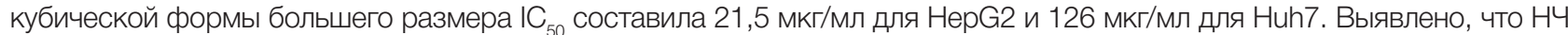
меньшего размера аккумулируются преимущественно в гепатоцитах печени, а НЧ большего размера - в селезенке, в печени же они накапливаются главным образом в макрофагах. Такая разница может быть вызвана большим гидродинамическим размером НЧ, которые имеют больший размер магнитного ядра. Образец с ядром меньшего размера является наиболее эффективной платформой для доставки антисмысловых препаратов в гепатоциты.

Ключевые слова: магнитные наночастицы, МРТ, липиды, адресная доставка

Финансирование: работа выполнена при поддержке Министерства образования и науки РФ, соглашение № 14.578 .21 .0201 (уникальный идентификатор RFMEFI57816Х0201).

Для корреспонденции: Виктория Игоревна Уварова

ул. Ленинский проспект, д. 4, г. Москва, 119049; uvarova_viktoriya@bk.ru

Статья получена: 26.06.2018 Статья принята к печати: 25.08.2018

DOI: $10.24075 /$ vrgmu.2018.080 
The term "hyperlipidemia" describes abnormally elevated levels of low-density lipoproteins and their metabolites in blood serum. Hyperlipidemia is a significant contributing factor in the risk of atherosclerosis and cardiovascular disorders [1], which, in turn, are a leading cause of death worldwide [2]. One of the approaches to treating this pathological condition is the silencing of genes responsible for elevated lipoproteins levels in plasma. [3, 4]. For example, lipoprotein levels can be lowered by inhibiting the synthesis of proteins participating in lipoprotein metabolism, such as angiopoietin-like protein 3 or apolipoproteins B and C3 produced by liver hepatocytes [5]. The major obstacles to safe and effective gene therapy aimed at reducing lipoprotein levels arise from the difficulties that complicate targeted delivery of antisense therapeutic agents to hepatocytes and the release of therapeutic agents from endocytic vesicles [6, 7].

Platforms for the delivery of antisense drugs are traditionally classified into viral and nonviral [8, 9]. Viruses effectively transport foreign genetic material to cells. However, intense debate is continuing about the safety of viral carriers: adenoviral vectors can induce a strong immune response and their retroviral counterparts pose a risk of insertional mutagenesis [10]. Nonviral delivery systems comprise vectors based on inorganic nanoparticles (NP) [11], liposomes [12, 13], and complexes with cationic lipids or polymers [14, 15].

Lipidoids are lipid-like materials holding great promise for effective targeted drug delivery. They can be used both as drug carriers and NP surface coatings for the subsequent loading of nucleic acids. RNA delivery systems based on the C12-200 lipidoid exhibit high efficacy in laboratory animals, including rodents and nonhuman primates [16]. Lipid nanoparticles need auxiliary components for better performance. Those include fusogenic phospholipids (DSPC), which improve transfection efficacy of the system by destabilizing the lipid bilayer of cell membranes, PEG lipids (mPEG2000-DMG), which reduce immune response by stabilizing LNP and protecting them from macrophages, and cholesterol, which fills the space between the lipid molecules on the NP surface and enhances the activity of cationic lipids [17].

Transfection methods vary greatly in their efficacy determined by the accuracy of drug delivery to a target cell, interactions between the carrier and the cell membrane and the release of the carrier from endosomes. Once endocytosed, nonviral vectors can get trapped by the endosomal compartment of the cell, suffering subsequent degradation of the therapeutic gene they carry [18]. New strategies are being sought to facilitate release of viral vectors from endosomes, which will naturally improve the efficacy of transfection.

Magnetic iron oxide NP offer a solution to the problem of poor transfection efficacy of nonviral vectors. Magnetite and maghemite nanoparticles have a few attractive properties beneficial for such biomedical applications as targeted drug delivery, magnetic hyperthermia, and contrast-enhanced MRI [19]. Importantly, magnetic NP can be used to attain controlled drug release in biological objects, including cells and experimental animals, made possible by the effect of Brownian relaxation, which in essence is intense oscillations of magnetic particles induced by a low-frequency magnetic field. This approach can significantly improve the efficacy of therapeutic agents: some researchers report that magnetic liposomes (liposomes enriched with magnetic NP) demonstrate better performance in the targeted delivery of doxorubicin and paclitaxel than their conventional counterparts [20, 21].

The functional properties of drug delivery systems based on magnetic NP are largely determined by their magnetic properties. For example, their suitability as contrast agents is influenced by their size and geometry [22].

In this study we attempted to design a platform for targeted delivery of antisense nucleic acids based on iron oxide nanocubes functionalized with a lipid formulation and to test the obtained carrier for the efficacy of drug delivery into hepatocytes in vivo.

\section{METHODS}

The following reagents were used: 1-octadecene, trioctylamine, dibenzyl ether, oleic acid, sodium oleate, iron oleate (III), anhydrous sodium acetate, cholesterol, 1,2-distearoyl-snglycero-3-phosphocholine (DSPC), 1,2-dimyristoyl-sn-glycero3-methoxypolyethylene glycol monomethyl ether (DMG-mPEG), $\mathrm{N}$-methyl-2-pyrrolidone (Sigma-Aldrich; USA), hydrochloric acid, nitric acid, ethanol, butanol-1, chloroform (SigmaTec; Russia), 1,1'-(2-(4-(2-((2-(bis(2-hydroxydodecyl)amino)ethyl) (2-hydroxydodecyl)amino)ethyl)piperazine-1-yl) ethylazanediyl) didodecane-2-ol (C12-200), DMEM and DMEM/F12, deionized water.

\section{Cell cultures}

The initial stock of Huh7 cells was provided by the Department of RNA Structure and Functions of A.N.Belozersky Research Institute of Physico-Chemical Biology. HepG2 cells were purchased from a cell bank (ATCC, HB-8065). Manipulations with the cells were carried out in the SafeFAST Elite 212 S sterile class II microbiological safety cabinet (Faster; Italy). The cells were cultured in the MCO-18AIC CO, Incubator (Sanyo; Japan) at $37{ }^{\circ} \mathrm{C}$ in $5 \% \mathrm{CO}_{2}$ environment. The culture medium for Huh7 cells was DMEM (Corning, catalog number 10-013CV) supplemented with $4.5 \mathrm{~g} / \mathrm{l}$ glucose, $10 \%$ fetal bovine serum and $4 \mathrm{mM}$ L-glutamine. HepG2 cells were cultured in DMEM/ F12 (Gibco ${ }^{\mathrm{TM}}$, catalog number 21331020) containing 10\% fetal bovine serum and $4 \mathrm{mM}$ L-glutamine.

\section{Animal model}

The experiments were carried out in adult female BALB/c mice (age of 6-7 weeks, weight of 19-20 g) purchased from the Central breeding nursery of the Academy of Medical Sciences (Andreevka; Russia) and kept in individually ventilated cages. The study was approved by the Ethics Committee of Pirogov Russian National Research Medical University (Protocol 1/2016 dated February 3, 2016).

\section{Synthesis of lipidoid nanocubes}

Precursor iron (III) oleate was synthesized following a protocol described in [23]. Magnetite nanocubes with an average size of $16 \mathrm{~nm}(\mathrm{CbS})$ were obtained through thermal decomposition of the precursor in a high-boiling organic solvent. The detailed description of the procedure is available in [24].

Nanocubes with an average size of $27 \mathrm{~nm}(\mathrm{CbB})$ were synthesized in two steps. In the first step, magnetic nuclei (seeds) were obtained as described above. In the second step, the precursor was introduced into the reaction mixture to stimulate NP growth. Briefly, $37.5 \mathrm{mg}$ of the seeds, $0.35 \mathrm{~g}$ of sodium oleate and $0.32 \mathrm{~g}$ of oleic acid were loaded into a three-neck flask equipped with a mercury thermometer. Then, a solvent mix was added consisting of $2.85 \mathrm{~g}$ trioctylamine and $3.13 \mathrm{~g}$ of dibenzyl ether. The resulting mixture was heated to $110^{\circ} \mathrm{C}$ under vigorous stirring under argon flow and maintained 
under such conditions for $1 \mathrm{~h}$. After that, the mixture was heated to a boiling temperature at a rate of $5^{\circ} \mathrm{C} / \mathrm{min}$. Subsequently, $20 \mathrm{ml}$ of $0.2 \mathrm{M}$ iron (III) oleate solution in dibenzyl ether were added dropwise to the mixture at $3 \mathrm{ml} / \mathrm{h}$, which was then left to boil for $20 \mathrm{~min}$ and cooled down to room temperature. The synthesized NP were separated from the reaction mixture by magnetic decantation in the presence of butanol-1. The precipitate was redispersed in chloroform and sonicated for 5-10 min.

The nanoparticles were coated with a lipidoid formulation using the phase transfer approach [25]. The coating consisted of the C12-200 lipidoid [26], cholesterol, DSPC and DMGmPEG taken at a mass ratio of $75: 15: 7: 3$. The mass percent of the lipid formulation used to coat $\mathrm{CbB}$ and $\mathrm{CbS}$ was 0.9 and $1 \%$ (relative to magnetite), respectively.

\section{Characterization of physical and chemical properties of the obtained nanoparticles}

\section{Transmission electron microscopy (TEM)}

The obtained nanoparticles were imaged under the JEOL 1200EX II transmission electron microscope (JEOL; Japan) operating at an accelerating voltage of $100 \mathrm{kV}$. Samples for TEM were prepared by applying 1-2 $\mu$ l of the NP solution onto a formvarcoated copper mesh $(d=3.05 \mathrm{~mm})$ that was subsequently left to air-dry. Further manipulations with images necessary to determine the distribution of NP sizes and characterize NP morphology was done in ImageJ ver. 1.50d (Wayne Rasband $(\mathrm{NIH})$; USA).

\section{$X$-ray diffraction analysis $(X R D)$}

The crystalline structure of the particles was studied by X-ray diffraction on the DRON-4 diffractometer (Burevestnik; Russia) with the following settings: CoKa radiation with $\lambda=0.179 \mathrm{~nm}$, tube voltage of $40 \mathrm{kV}$, and current of $30 \mathrm{~mA}$. The samples were scanned through a range of diffraction angles $2 \theta$ from $20^{\circ}$ to $120^{\circ}$ by increments of $0.1^{\circ}$. Exposure time was 3 seconds per frame. Phases were identified by comparing the obtained data to the database of about 200,000 X-ray spectra in PHAN software.

Thermal gravimetric analysis and differential scanning calorimetry (TGAVDSC)

TGA and DSC were performed using the simultaneous thermal analyzer Netzsch STA 449 F3 (NETZSCH; Germany). The

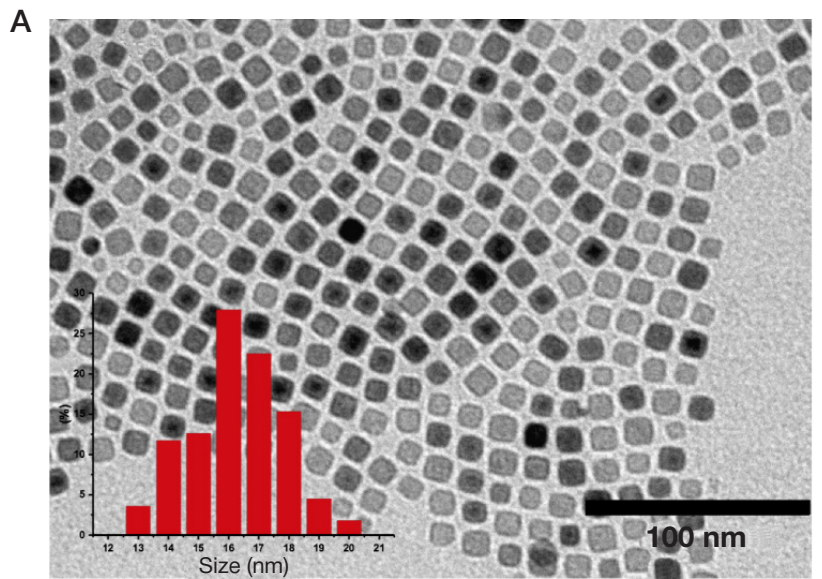

samples were placed into alundum crucibles and heated in the temperature range from 50 to $800^{\circ} \mathrm{C}$ at $10{ }^{\circ} \mathrm{C} / \mathrm{min}$ under argon flow. Before the analysis, solvents were removed from the samples by evaporation using a rotary evaporator.

\section{Vibrating-sample magnetometry}

Static magnetic properties of the nanoparticles were profiled by applying a range of magnetic fields from -20 to $20 \mathrm{kOe}$ at $300 \mathrm{~K}$. Measurements were done using the Quantum Design Physical Property Measurement System (PPMS; Germany) equipped with a vibrating sample magnetometer with an oscillation amplitude of $2 \mathrm{~mm}$ and frequency of $40 \mathrm{~Hz}$. The sensitivity of the system was $10^{-6}$ emu.

\section{Photon correlation spectroscopy (PCS)}

The hydrodynamic sizes and ろ-potential (charge) of the particles coated with a lipid formulation were measured by PCS in $0.5 \mathrm{mg} / \mathrm{ml}$ LNP solutions in phosphate-buffered saline ( $1 \times P B S)$ or distilled water. The solutions were poured into plastic or glass cuvettes. The analysis was carried out at $25^{\circ} \mathrm{C}$ using Zetasizer Nano ZS (Malvern; Germany). The Z-potential of the particles was measured in distilled water using disposable capillary cuvettes for $\zeta$-potential measurements.

\section{Cytotoxicity of lipidoid nanoparticles in vitro}

LNP cytotoxicity was assessed by the MTS-assay (3-(4,5-dimethylthiazol-2-yl)-5-(3-carboxymethoxyphenyl)-2(4-sulfophenyl)-2H-tetrazolium) [27]. Human hepatocellular carcinoma cells (Huh7 and HepG2) were seeded onto 96well plates at 5,000 cells per well and cultured at $37^{\circ} \mathrm{C}$ in $5 \%$ $\mathrm{CO}_{2}$ environment until $70 \%$ confluence of the monolayer was achieved, which took 48 hours. Then, CbS and CbB were introduced into the wells at magnetite concentrations of 370 , $187,94,47,23,12$, and $6 \mu \mathrm{g} / \mathrm{ml}$ and $420,210,105,52,26,13$, and $6 \mu \mathrm{g} / \mathrm{ml}$, respectively. After that, the cells were incubated at $37^{\circ} \mathrm{C}$ in $5 \% \mathrm{CO}_{2}$ for $24 \mathrm{~h}$ and washed. Then, the MTS reagent was added to the wells. Cells incubated in a culture medium supplemented with equivalent volumes of phosphate buffered saline (1×PBS) were used for control. Optical density was measured using the plate reader VictorX3 (PerkinElmer; USA) at $\lambda=490 \mathrm{~nm}$. The proportion of the survived cells was calculated as a ratio of optical density of cells treated with nanoparticles to the optical density of untreated controls. Graphs were constructed and $\mathrm{IC}_{50}$ (half-maximal inhibitory concentration) was calculated in GraphPad Prism 8.0.0 (GraphPad Software; USA).

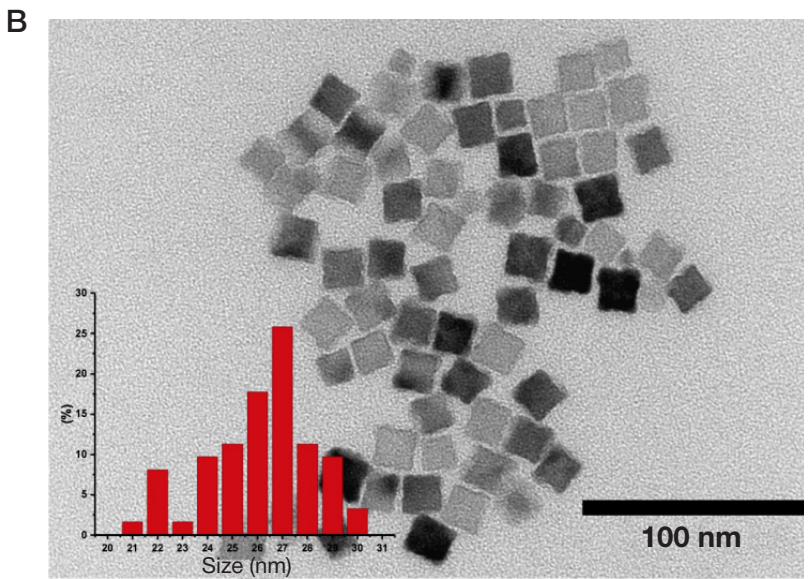

Fig. 1. A TEM image and a size distribution histogram of the magnetite nanoparticles: size range of 10 to $20 \mathrm{~nm}$ (A); size range of 20 to $30 \mathrm{~nm}$ (B) 


\section{Study of biodistribution of nanoparticles}

Biodistribution of LNP was studied in BALB/c mice divided into 3 groups of 3 . The animals from the experimental group received $120 \mu \mathrm{l}$ of the LNP solution (an iron concentration of $720 \mu \mathrm{g} / \mathrm{ml}$ ) intravenously. The control group did not receive any injections.

\section{Studying the dynamics of LNP accumulation by MRI}

The animals were scanned by the $7 \mathrm{~T}$ animal MRI scanner ClinScan (Bruker Biospin; USA). Transverse T2-weighted images were obtained in the fat-suppression mode with the following Turbo Spin Echo (TSE) parameters: TR/TE $=2000 / 42 \mathrm{~ms}$, slice thickness $=1 \mathrm{~mm}$, matrix $=380 \times 640, \mathrm{FOV}=34 \times 60 \mathrm{~mm}$. To assess the dynamics of NP accumulation, scans were performed before the LNP injection and 1, 12, 24, and 48 hours after it.

\section{Histological examination}

Forty-eight hours after the LNP injection, the animals were euthanized with a lethal dose of Zoleti ${ }^{\circledR}$ injected intraperitoneally. After the reflexes were gone, the abdominal cavity was opened by a midline incision. The rib cage was cut laterally on both sides, perpendicular to the rib bones. The right atrium was dissected and perfused with $40 \mathrm{ml}$ of PBS. The solution was supplied through a needle introduced into the left ventricle and attached to a Janet's syringe via a cannula. Then the cervical vertebrae were dislocated and the organs were excised, including the liver, spleen, kidneys, and lungs. The removed organs were submerged in $4 \%$ paraformaldehyde and stored at $4{ }^{\circ} \mathrm{C}$ until further analysis. Sixty- $\mu \mathrm{m}$-thick slices were prepared using the Thermo Scientific Microm HM 650 V Vibration system
(Thermo Fisher Scientific; USA) and Perls-stained using the Iron Stain Kit (Sigma-Aldrich; USA). Perls staining involves treating histological slices with a mixture of hydrochloric acid and potassium hexacyanoferrate (II). The reaction between the mixture and the deposits of iron compounds in a histological slice produces a Prussian blue pigment. Its granules of different shades of blue can be seen under a light microscope. The samples were washed in distilled water twice, incubated in 70\% glycerol and imaged under a light microscope by Carl Zeiss (Germany) equipped with Axioplan 2 Imaging camera.

Biodistribution of iron in the internal organs of mice assessed by inductively coupled plasma atomic emission spectroscopy (AES)

Paraformaldehyde-fixed organ fragments (one-third of the liver and spleen, one kidney, one lung and a half of the heart) were dissolved in $2 \mathrm{ml}$ of a freshly prepared mix consisting of 1,500 $\mu \mathrm{l}$ of concentrated hydrochloric acid $(\mathrm{HCl})$ and $500 \mu \mathrm{l}$ of nitric acid $\left(\mathrm{HNO}_{3}\right)$. The fragments were incubated in the acid mix for $24 \mathrm{~h}$. Then, water was added to bring the volume of the dissolved liver and spleen to $20 \mathrm{ml}$ and of the heart, kidney and lung, to $10 \mathrm{ml}$. After the calibration curve was constructed, iron concentrations were measured in the obtained solutions using the 4200 MP-AES machine (Agilent Technologies; USA).

\section{RESULTS}

TEM images of monodisperse nanocubes with an average size of $16 \mathrm{~nm}(\mathrm{CbS})$ and histograms of their size distribution are presented in Fig. 1A. TEM images of bigger nanocubes (CbB) sized 20-30 nm show that CbB samples have distinct morphology and a well-faceted cubic shape (Fig. 1 B).
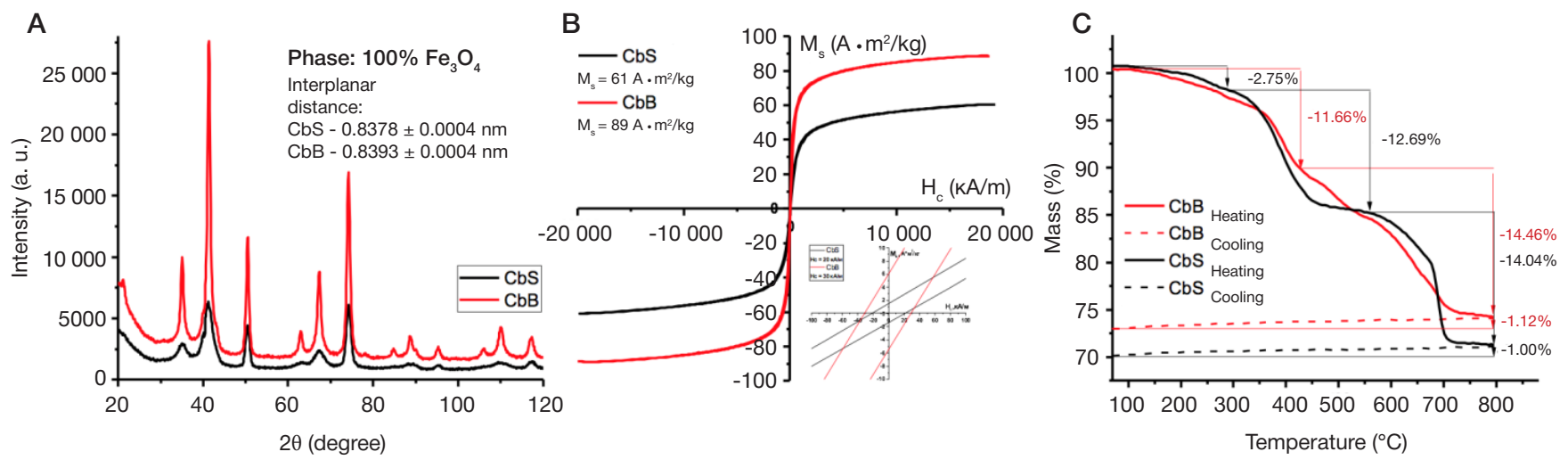

Fig. 2. Physical and chemical properties of nanocubes: X-ray diffraction analysis (A); hysteresis loops (B); TGA/DSC (C)

A

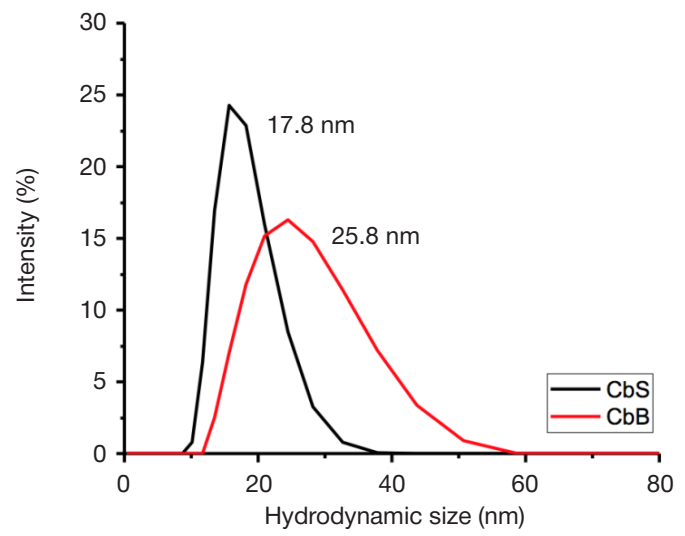

B

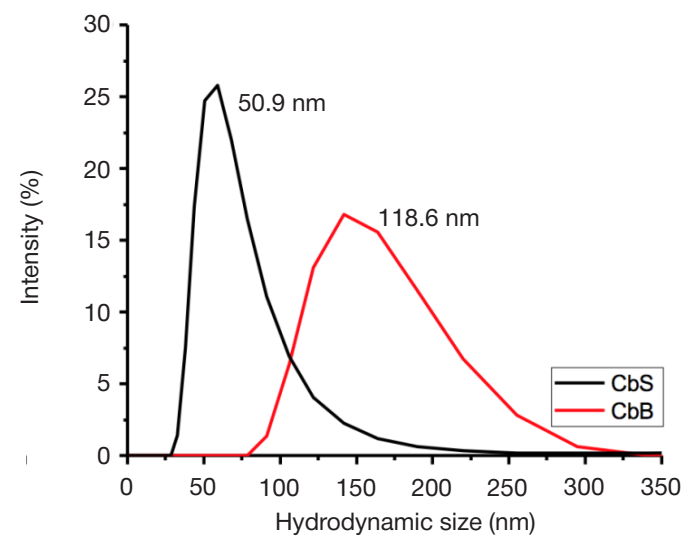

Fig. 3. A. Hydrodynamic size of uncoated nanocubes in chloroform. B. Hydrodynamic size of lipid-coated nanoclusters in water 
X-ray diffraction analysis yielded very similar results for both $\mathrm{CbS}$ and $\mathrm{CbB}$ samples: the positions of diffraction peaks in the diffraction pattern correspond to the inverse spinel structure of magnetite with lattice constants of $0.838 \mathrm{~nm}$ and $0.839 \mathrm{~nm}$ for $\mathrm{CbS}$ and $\mathrm{CbB}$, respectively (Fig. 2A). Hysteresis loops (Fig. 2 B) indicate that $\mathrm{CbS}$ and $\mathrm{CbB}$ are ferrimagnetic materials with coercivity of $20-30 \mathrm{kA} / \mathrm{m}$. Magnetic saturation (Ms) of $\mathrm{CbS}$ is $61 \mathrm{~A} \cdot \mathrm{m}^{2} / \mathrm{kg}$. Large nanocubes $(\mathrm{CbB})$ have $\mathrm{Ms}$ of $89 \mathrm{~A} \cdot \mathrm{m}^{2} / \mathrm{kg}$. In our study, magnetic saturation was normalized to the amount of the iron oxide phase (minus the mass of organic stabilizers) determined by TGA/DSC (Fig. 2C).

The TG curve constructed for $\mathrm{CbS}$ has three regions indicating abrupt weight loss: the first recorded at $150-300^{\circ} \mathrm{C}$ corresponds to the desorption of organic compounds noncovalently bound to the surface of NP; the second recorded at $300-450{ }^{\circ} \mathrm{C}$ corresponds to the desorption of covalently bound stabilizers; the third recorded over a temperature range of $600-700{ }^{\circ} \mathrm{C}$ occurs when magnetite undergoes phase transition. The region of the CbB TG curve showing desorption of covalently and noncovalently bound organic molecules looks smoother; phase transition is observed at temperatures over $500{ }^{\circ} \mathrm{C}$.

Nanocubes with hydrophobic residues of oleic acid on their surface can be dispersed in nonpolar organic solvents (chloroform, hexane) and can be regarded as a colloid system resistant to sedimentation. The average hydrodynamic size of $\mathrm{CbS}$ and $\mathrm{CbB}$ in chloroform is shown in Fig. 3A. The polydispersity index $(\mathrm{Pdl})$ is 0.113 and 0.151 for NP with an actual average sample of 16 and $27 \mathrm{~nm}$, respectively. To stimulate the phase transfer of magnetite NP to an aqueous phase, the particles were coated with a lipid formulation consisting of the lipidoid C12-200, cholesterol, DSPC, and 1,2-DMG-mPEG taken at a mass ratio of $75: 15: 7: 3$. The average hydrodynamic size of the coated $\mathrm{CbS}$ in the aqueous phase increased to $50.9 \mathrm{~nm}$

A

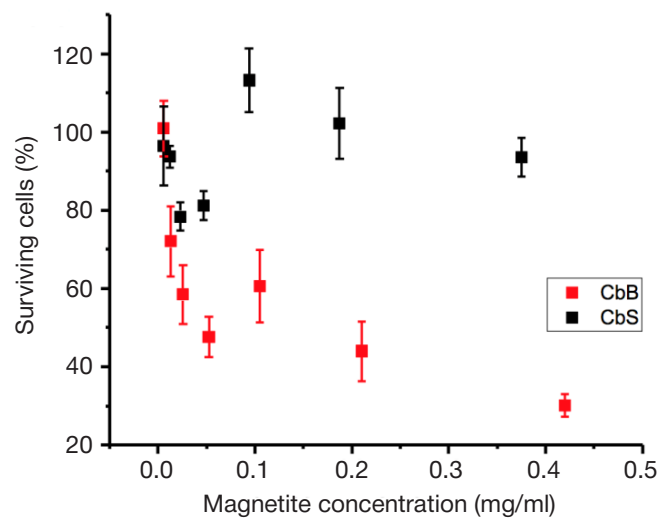

$(\mathrm{Pdl}=0.119)($ Fig. 3B). Based on the size distribution pattern, we inferred that the majority of $\mathrm{CbS}$ nanocubes were present in the solution as individual particles, while the minority tended to aggregate into clusters. The pattern of $\mathrm{CbB}$ size distribution was completely opposite: the average hydrodynamic size of $\mathrm{CbB}$ particles was $118.6 \mathrm{~nm}(\mathrm{Pdl}=0.201)$ (Fig. 3B), which is 4 times bigger than their actual size, suggesting more vigorous aggregation of nanocubes functionalized with lipids. The value of the Z-potential of magnetite-based LNP in water was positive and equaled $+20.5 \mathrm{mV}$ and $+34.3 \mathrm{mV}$ for $\mathrm{CbB}$ and $\mathrm{CbS}$, respectively.

The survival of HepG2 and Huh7 cells incubated with CbS and $\mathrm{CbB}$ is shown in Fig.4. Using the MTS assay, we calculated IC50 for CbB: it was $21.5 \mu \mathrm{kg} / \mathrm{ml}$ (magnetite concentration) for HepG2 and $126 \mu \mathrm{kg} / \mathrm{ml}$, which is 6 times higher, for Huh7. CbS did not exhibit any cytotoxic activity at studied concentrations.

Fig. 5A features representative T2-weighted coronal images that clearly show that the most pronounced NP accumulation could be observed in the liver and spleen of the experimental mice 0-48 $\mathrm{h}$ after the intravenous injection of the formulation. The accumulation of both $\mathrm{CbS}$ and $\mathrm{CbB}$ was noticeable as early as 1 hour after the injection and its level remained stable for the next 48 hours. This suggests that intravenously injected NP are readily taken up by the liver and spleen. It should be born in mind, though, that $\mathrm{MRI}$ is a semi-quantitative modality and cannot be used to conclusively distinguish between the accumulation patterns of different NP types in different organs. Therefore, we additionally employed AES to study iron accumulation in the internal organs of the experimental mice (Fig. 5B). AES revealed that LNP tended to be sequestered mostly by the liver and spleen, which was consistent with MRI findings (Fig. 5A). LNP deposition in other organs was negligible. The CbS sample accumulated in the liver most effectively: the liver retained $84 \%$ of the injected LNP amount, whereas CbB

B

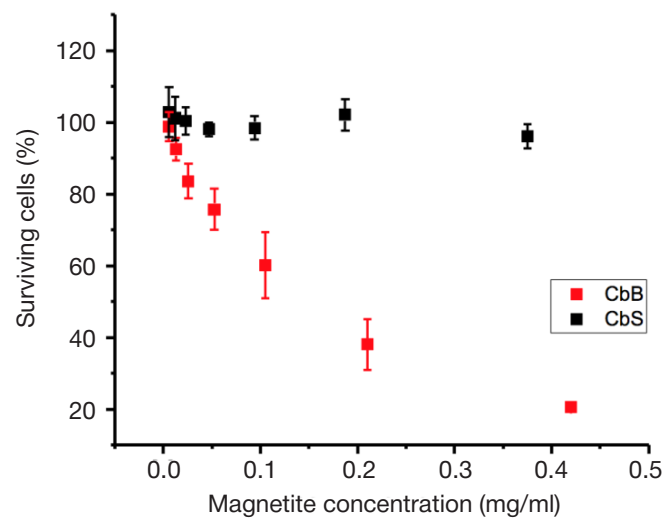

Fig. 4. Cytotoxicity of different concentrations of lipidoid-coated $\mathrm{CbS}$ and $\mathrm{CbB}$ nanoclusters with magnetic core against HepG2 (A) and Huh7 (B) cell lines
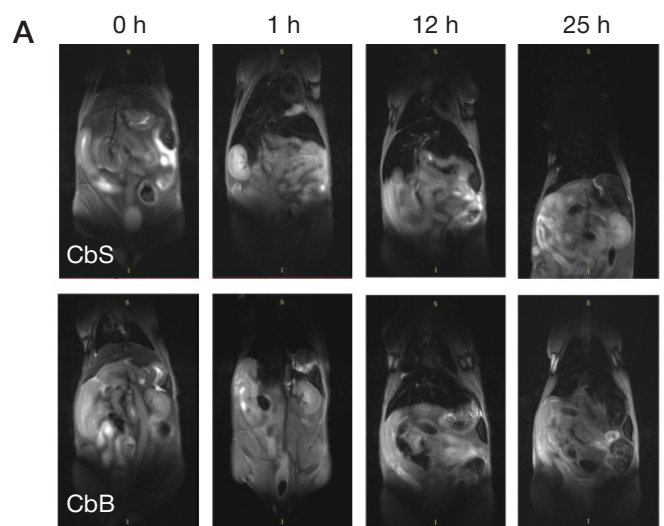

$48 \mathrm{~h}$
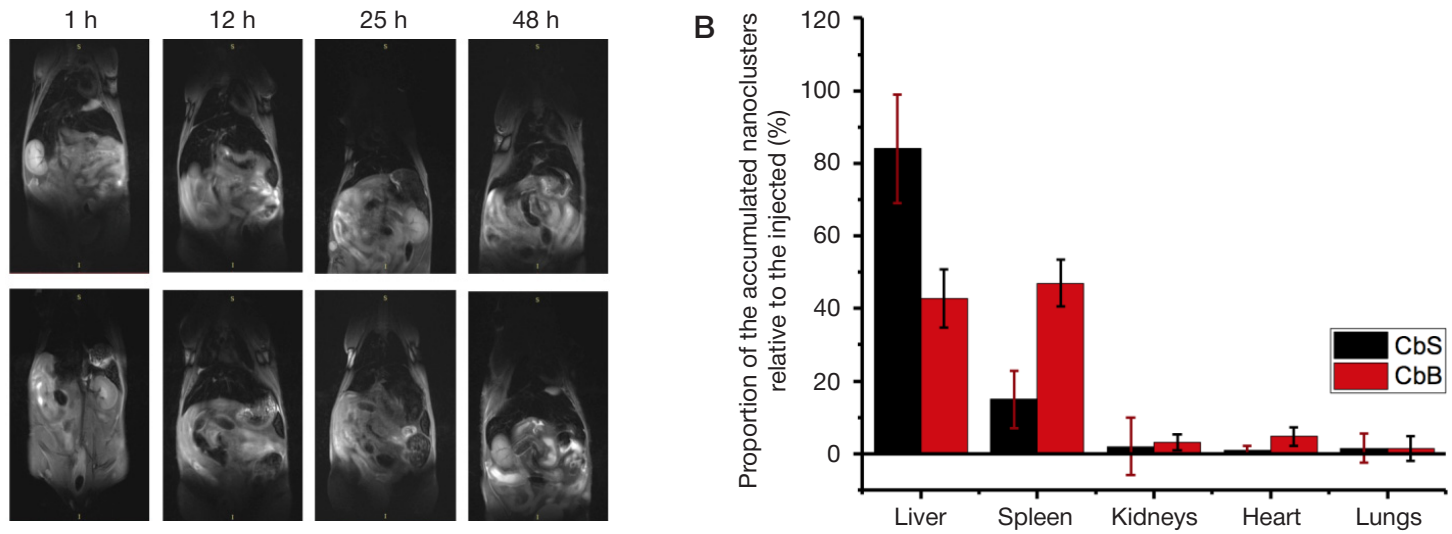

Fig. 5. Distribution of magnetic core CbS and CbB nanoclusters in the liver and spleen visualized by MRI (A); in all studied internal organs measured by AES (B) 

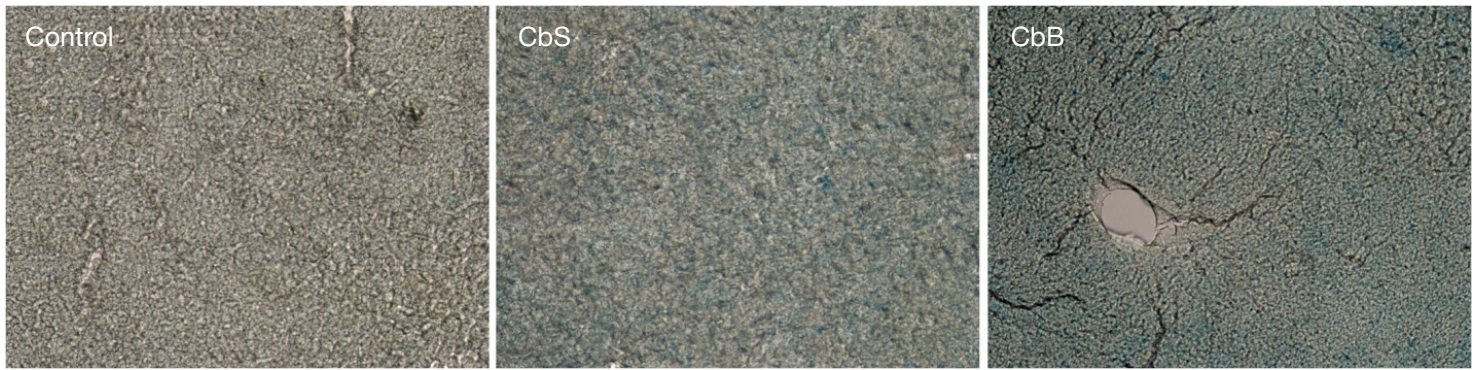

Fig. 6. Distribution of magnetic core $\mathrm{CbS}$ and $\mathrm{CbB}$ nanoclusters in liver cells (Perls reaction)

showed poor accumulation in this organ (only $43 \%$ of the injected LNP amount).

The images of Perls-stained liver slices clearly demonstrate that both types of iron-based NP increasingly build up in the liver in comparison with the controls (Fig. 6). There was a difference in the pattern of iron accumulation between the CbS and $\mathrm{CbB}$ samples. CbS diffusely spread in the liver parenchyma (presumably, depositing in hepatocytes), whereas $\mathrm{CbB}$ exhibited a mixed discoloration pattern: some of the particles deposited in irregular-shaped cells (presumably, macrophages) lying at the border between the sinusoids and the parenchyma, and some produced diffuse discoloration evident of their buildup in hepatocytes.

\section{DISCUSSION}

The classic process of NP growth can be broken down into 3 stages: in the first stage, the precursor - iron (III) oleate decomposes producing unstable iron-organic intermediates until their critical concentration is reached necessary for nucleation. In the second stage, the concentration of the intermediates declines as these molecules attach to the surface of magnetic seeds stimulating their growth. In the last stage, the concentration of the intermediates drops to thermodynamically stable levels, and the generated NP undergo Ostwald ripening. A steady rate of NP growth can be maintained by the controlled addition of a precursor, making NP expand in size while retaining their monodispersity. Using this approach, one can synthesize NP with a programmed size (as large as required) characterized by low polydispersity, which is particularly important for the particles with dimensions over $20 \mathrm{~nm}$. When added to the reaction mixture, a stabilizer (potassium oleate) that can be specifically adsorbed onto the plane (111) promotes formation of cube-shaped nanoparticles (Fig. 1B). In our study, the rate at which the precursor was supplied to the mixture in the second stage of synthesis, its concentration and duration of its addition were determined experimentally. At low rates, NP underwent Ostwald ripening: the mass was transferred from small particles to large, promoting polydispersity. At high rates, the concentration of intermediates in the reaction mixture surged triggering the mechanism of primary nucleation and increasing NP polydispersity.

For both samples, the results of the conducted X-ray diffraction analysis are consistent with the literature [28].

For CbS, magnetic saturation (Ms) agrees with the values reported for average-sized magnetite NP comparable in their dimensions with CbS particles [23, 29]. The Ms of large cubeshaped NP (CbB) was very high and comparable to that of a massive sample [30] or huge NP [31].

According to the results of the TGA/DSC analysis (Fig. 2C), the amount of the organic phase adsorbed onto the surface of iron oxide NP constitutes $15.5 \%$ of the total $\mathrm{CbS}$ and $11.7 \%$ of the total $\mathrm{CbB}$ masses. For samples with similar masses, an increase in the average size of NP entails an increase in the ratio of their surface area to their volume. The process yields more stabilizing molecules that can be adsorbed onto the NP surface. This significantly affects the stability of the studied colloidal system largely determined by 2 factors: steric stabilization ensured by the presence of long hydrophobic residues of oleic acid adsorbed onto the surface of NP and the aggregation of those residues caused by mutual magnetism. As the magnetic core grows, the Pdl of the CbB sample increases (as demonstrated by PCS) and the peak of its hydrodynamic size broadens, as compared to CbS, suggesting more vigorous clusterization of the particles resulting from the magnetic core growth, which, in turn, is caused by intense magnetic interactions.

The hydrodynamic size of NP and the physical and chemical properties of their surface largely determine the pattern of intercellular interactions, endocytic routes and the efficacy of NP uptake by the cell $[32,33]$. The internalization of NP into cells causes disorganization of the cytoskeleton [34, 35]. When accumulated in abundance, NP induce disruption of the actin and microtubule networks in neural progenitor cells of mice and primary endothelial cells of human blood vessels [36]. We hypothesized that the mere physical presence of sufficient amounts of NP captured by large lysosomal structures normally found near the nucleus sterically impairs the function of the cytoskeleton and causes reorganization of the actin network. The results of cytotoxicity tests correlate well with a hypothesis that establishes a link between the disruption of the cytoskeleton and NP toxicity: the studied concentrations of the CbB sample, whose actual size was 1.7 bigger than that of $\mathrm{CbS}$, were toxic against the used cell lines, unlike CbS, whose phase composition, coating and morphology were similar.

The initial characteristics of magnetic NP, including size and shape homogeneity, resistance to aggregation, and stability of the coating, are key to the pharmacokinetics and biodistribution of the particles. It is well known that NP with the hydrodynamic size of less than $20-30 \mathrm{~nm}$ are filtered by renal glomeruli and those over $200 \mathrm{~nm}$ in size build up in the liver [37]. Nanoparticles with the dimensions between 30 and $200 \mathrm{~nm}$ are normally sequestered in the liver: they can be easily captured by endocytic vesicles with an average diameter of 40-60 nm. However, particles over $150 \mathrm{~nm}$ in size (the upper limit for entering the cell through caveolae) are engulfed by macrophages. Therefore, an ideal hydrodynamic LNP size to be taken up by the liver would be 30 to $150 \mathrm{~nm}$. The histological examination and the analysis of NP biodistribution in the organs of mice reveal that the $\mathrm{CbB}$ particles are mainly accumulated in the reticuloendothelial system, which explains the even distribution of NP between the liver and spleen. These findings correlate well with other studies [38]. In contrast, the CbS sample is not sequestered in macrophages but is caught by hepatocytes instead, leading to its buildup in the liver. This fact is consistent with the literature describing the behavior of 
NP with a magnetic core of a comparable size [39]. Perhaps, larger nanocubes $(\mathrm{CbB})$ grow in size when introduced into the bloodstream of a mouse because they adsorb serum proteins on the surface which form a crown of biomolecules [40], thereby increasing the hydrodynamic size of NP; as a result, the latter accumulate in the spleen.

\section{CONCLUSIONS}

The proposed platform for the delivery of antisense drugs into liver hepatocytes has proved to be effective both in vivo and in vitro. The synthesized CbS lipid-coated nanoparticles exhibit low toxicity against Huh7 and HepG2 cell lines. The analysis of in vivo biodistribution of differently sized LNP with magnetic cores reveals significant accumulation of the particles in the liver as early as 1 hour after the injection. The level of accumulation remained stable for 48 hours following the injection. Nanocubes with magnetic iron oxide cores sized 10 to $20 \mathrm{~nm}$ and a hydrodynamic size of $<100 \mathrm{~nm}$ increasingly accumulated in hepatocytes (>80\% of the injected dose) whereas larger NP were readily taken up by Kupffer cells and other components of the reticuloendothelial system.

\section{References}

1. Wouters K, Shiri-Sverdlov R, van Gorp PJ, van Bilsen M, Hofker MH. Understanding hyperlipidemia and atherosclerosis: lessons from genetically modified apoe and Idlr mice. Clin Chem Lab Med [Internet]. 2005 [cited 2017 Oct 28]; 43 (5): 470-9. Available from: http://www.ncbi.nlm.nih.gov/pubmed/15899668.

2. Pagidipati NJ, Gaziano TA. Estimating Deaths From Cardiovascular Disease: A Review of Global Methodologies of Mortality Measurement. Circulation. 2013; 127 (6): 749-56.

3. Sullenger BA, Nair S. From the RNA world to the clinic. Science 17. 2016; 352 (6292): 1417-20.

4. McClorey G, Wood MJ. An overview of the clinical application of antisense oligonucleotides for RNA-targeting therapies. Curr Opin Pharmacol. 2015; (24): 52-8.

5. Kulkarni JA, Cullis PR, van der Meel R. Lipid Nanoparticles Enabling Gene Therapies: From Concepts to Clinical Utility. Nucleic Acid Ther. 2018; 28 (3): 146-57.

6. Mahajan UM, Teller S, Sendler M, Palankar R, van den Brandt C, Schwaiger $\mathrm{T}$ et al. Tumour-specific delivery of siRNA-coupled superparamagnetic iron oxide nanoparticles, targeted against PLK1, stops progression of pancreatic cancer. Gut. 2016; 65 (11): 1838-49.

7. Kim M-C, Lin MM, Sohn Y, Kim J-J, Kang BS, Kim DK. Polyethyleneimine-associated polycaprolactone-Superparamagnetic iron oxide nanoparticles as a gene delivery vector. J Biomed Mater Res Part B Appl Biomater. 2017; 105 (1): 145-54.

8. Nayerossadat N, Ali P, Maedeh T. Viral and nonviral delivery systems for gene delivery. Adv Biomed Res. 2012; 1 (1): 27

9. Yang N. An overview of viral and nonviral delivery systems for microRNA. Int J Pharm Investig. 2015; 5 (4): 179.

10. Nayak S, Herzog RW. Progress and prospects: immune responses to viral vectors. Gene Ther. 2010; 17 (3): 295-304.

11. Qiu J, Kong L, Cao X, Li A, Wei P, Wang L et al. Enhanced Delivery of Therapeutic siRNA into Glioblastoma Cells Using DendrimerEntrapped Gold Nanoparticles Conjugated with $\beta$-Cyclodextrin. Nanomaterials. 2018; 8 (3): 131.

12. Singh $\mathrm{Y}$, Tomar $\mathrm{S}$, Khan S, Meher JG, Pawar VK, Raval $\mathrm{K}$ et al. Bridging small interfering RNA with giant therapeutic outcomes using nanometric liposomes. J Control Release. 2015; (220): 368-87.

13. Leung AK, Tam YY, Cullis PR. Lipid Nanoparticles for Short Interfering RNA Delivery. Adv Genet. 2014; (88): 71-110.

14. Nakamura $T$, Yamada $K$, Fujiwara $Y$, Sato $Y$, Harashima $H$, Reducing the Cytotoxicity of Lipid Nanoparticles Associated with a Fusogenic Cationic Lipid in a Natural Killer Cell Line by Introducing a Polycation-Based siRNA Core. Mol Pharm. 2018; 15 (6): 2142-50.

15. Jin M, Jin G, Kang L, Chen L, Gao Z, Huang W. Smart polymeric nanoparticles with $\mathrm{pH}$-responsive and PEG-detachable properties for co-delivering paclitaxel and survivin siRNA to enhance antitumor outcomes. Int J Nanomedicine. 2018; (13): 2405.

16. Novobrantseva TI, Borodovsky A, Wong J, Klebanov B, Zafari M, Yucius $\mathrm{K}$ et al. Systemic RNAi-mediated Gene Silencing in Nonhuman Primate and Rodent Myeloid Cells. Mol Ther Nucleic Acids. 2012; (1): e4.

17. Kumar V, Qin J, Jiang $Y$, Duncan RG, Brigham B, Fishman $S$ et al. Shielding of Lipid Nanoparticles for siRNA Delivery: Impact on Physicochemical Properties, Cytokine Induction, and Efficacy. Mol Ther Nucleic Acids. 2014; (3): e210.

18. Alshehri A, Grabowska A, Stolnik S. Pathways of cellular internalisation of liposomes delivered siRNA and effects on siRNA engagement with target mRNA and silencing in cancer cells. Sci Rep. 2018; 8 (1): 3748.

19. Soenen SJ, Hodenius M, De Cuyper M. Magnetoliposomes: versatile innovative nanocolloids for use in biotechnology and biomedicine. Nanomedicine. 2009; 4 (2): 177-91.

20. Dobson J. Magnetic nanoparticles for drug delivery. Drug Dev Res [Internet]. 2006 [cited 2017 Sep 18]; 67(1): 55-60. Available from: http://onlinelibrary.wiley.com/doi/10.1002/ddr.20067/abstract.

21. Zhang JQ, Zhang ZR, Yang H, Tan QY, Qin SR, Qiu XL. Lyophilized paclitaxel magnetoliposomes as a potential drug delivery system for breast carcinoma via parenteral administration: in vitro and in vivo studies. Pharm Res [Internet]. 2005 [cited 2017 Sep 18]; 22 (4): 573-83. Available from: http://www.ncbi.nlm.nih.gov/ pubmed/15846465.

22. Yang L, Wang Z, Ma L, Li A, Xin J, Wei R et al. The Roles of Morphology on the Relaxation Rates of Magnetic Nanoparticles. ACS Nano. 2018; 12 (5): 4605-14.

23. Bronstein LM, Huang X, Retrum J, Schmucker A, Pink M, Stein BD et al. Influence of Iron Oleate Complex Structure on Iron Oxide Nanoparticle Formation. 2007 [cited 2017 Dec 16]; 19 (15): 3624-32. Available from: http://pubs.acs.org/doi/abs/10.1021/ cm062948j.

24. Hai HT, Yang HT, Kura H, Hasegawa D, Ogata Y, Takahashi M et al. Size control and characterization of wustite (core)/spinel (shell) nanocubes obtained by decomposition of iron oleate complex. J Colloid Interface Sci [Internet]. 2010; 346 (1): 37-42. Available from: http://dx.doi.org/10.1016/j.jcis.2010.02.025.

25. Jiang S, Eltoukhy A, Love K, Langer R, Anderson D. LipidoidCoated Iron Oxide Nanoparticles for Efficient DNA and siRNA delivery. Nano Lett [Internet]. 2013; 1-6. Available from: citeulikearticle-id:12014954\%5Cnhttp://dx.doi.org/10.1021/nl304287a.

26. Love KT, Mahon KP, Levins CG, Whitehead KA, Querbes W, Dorkin JR et al. Lipid-like materials for low-dose, in vivo gene silencing. Proc Natl Acad Sci. 2010; 107 (5): 1864-9.

27. Mosmann T. Rapid colorimetric assay for cellular growth and survival: Application to proliferation and cytotoxicity assays. J Immunol Methods. 1983; 65 (1-2): 55-63.

28. Mamani JB, Costa-Filho AJ, Cornejo DR, Vieira ED, Gamarra LF. Synthesis and characterization of magnetite nanoparticles coated with lauric acid. Mater Charact. 2013; (81): 28-36.

29. Nemati Z, Das R, Alonso J, Clements E, Phan MH, Srikanth H. Iron Oxide Nanospheres and Nanocubes for Magnetic Hyperthermia Therapy: A Comparative Study. J Electron Mater [Internet]. 2017 [cited 2017 Dec 16]; 46 (6): 3764-9. Available from: http://link. springer.com/10.1007/s11664-017-5347-6.

30. Cullity BD, Graham CD. Introduction to magnetic materials. 2nd ed. Hoboken, NJ: IEEE/Wiley, 2009; 544 p.

31. Marciello M, Connord V, Veintemillas-Verdaguer S, Vergés MA, Carrey J, Respaud M, et al. Large scale production of biocompatible 
magnetite nanocrystals with high saturation magnetization values through green aqueous synthesis. J Mater Chem B. 2013; 1 (43): 5995-6004.

32. Verma A, Stellacci F. Effect of Surface Properties on NanoparticleCell Interactions. Small. 2010; 6 (1): 12-21.

33. Adler AF, Leong KW. Emerging links between surface nanotechnology and endocytosis: Impact on nonviral gene delivery. Nano Today. 2010; 5 (6): 553-69.

34. Gupta AK, Gupta M. Cytotoxicity suppression and cellular uptake enhancement of surface modified magnetic nanoparticles. Biomaterials [Internet]. 2005 [cited 2017 Jun 9]; 26 (13): 1565-73. Available from: http://www.ncbi.nlm.nih.gov/pubmed/15522758.

35. Gupta AK, Curtis AS. Lactoferrin and ceruloplasmin derivatized superparamagnetic iron oxide nanoparticles for targeting cell surface receptors. Biomaterials. 2004; 25 (15): 3029-40.

36. Soenen SJH, Nuytten N, De Meyer SF, De Smedt SC, De Cuyper M. High Intracellular Iron Oxide Nanoparticle Concentrations Affect Cellular Cytoskeleton and Focal Adhesion Kinase-Mediated Signaling. Small. 2010; 6 (7): 832-42.
37. Berry CC. Progress in functionalization of magnetic nanoparticles for applications in biomedicine. J Phys D Appl Phys. 2009; 42 (22): 224003

38. Zhang J, Ring HL, Hurley KR, Shao Q, Carlson CS, Idiyatullin D et al. Quantification and biodistribution of iron oxide nanoparticles in the primary clearance organs of mice using T1 contrast for heating. Magn Reson Med [Internet]. 2017 [cited 2017 Dec 22]; 78 (2): 702-12. Available from: http://www.ncbi.nlm.nih.gov/ pubmed/27667655.

39. Bargheer D, Giemsa A, Freund B, Heine M, Waurisch C, Stachowski GM et al. The distribution and degradation of radiolabeled superparamagnetic iron oxide nanoparticles and quantum dots in mice. Beilstein J Nanotechnol. 2015; (6): 111-23.

40. Ruiz A, Hernández Y, Cabal C, González E, Veintemillas-Verdaguer S, Martínez E, et al. Biodistribution and pharmacokinetics of uniform magnetite nanoparticles chemically modified with polyethylene glycol. Nanoscale. 2013; 5 (23): 11400-8.

\section{Литература}

1. Wouters K, Shiri-Sverdlov R, van Gorp PJ, van Bilsen M, Hofker MH. Understanding hyperlipidemia and atherosclerosis: lessons from genetically modified apoe and Idlr mice. Clin Chem Lab Med [Internet]. 2005 [cited 2017 Oct 28]; 43 (5): 470-9. Available from: http://www.ncbi.nlm.nih.gov/pubmed/15899668.

2. Pagidipati NJ, Gaziano TA. Estimating Deaths From Cardiovascular Disease: A Review of Global Methodologies of Mortality Measurement. Circulation. 2013; 127 (6): 749-56.

3. Sullenger BA, Nair S. From the RNA world to the clinic. Science 17. 2016; 352 (6292): 1417-20.

4. McClorey G, Wood MJ. An overview of the clinical application of antisense oligonucleotides for RNA-targeting therapies. Curr Opin Pharmacol. 2015; (24): 52-8.

5. Kulkarni JA, Cullis PR, van der Meel R. Lipid Nanoparticles Enabling Gene Therapies: From Concepts to Clinical Utility. Nucleic Acid Ther. 2018; 28 (3): 146-57.

6. Mahajan UM, Teller S, Sendler M, Palankar R, van den Brandt C, Schwaiger $T$ et al. Tumour-specific delivery of siRNA-coupled superparamagnetic iron oxide nanoparticles, targeted against PLK1, stops progression of pancreatic cancer. Gut. 2016; 65 (11) 1838-49

7. Kim M-C, Lin MM, Sohn Y, Kim J-J, Kang BS, Kim DK Polyethyleneimine-associated polycaprolactone-Superparamagnetic iron oxide nanoparticles as a gene delivery vector. J Biomed Mater Res Part B Appl Biomater. 2017; 105 (1): 145-54.

8. Nayerossadat $\mathrm{N}$, Ali $\mathrm{P}$, Maedeh T. Viral and nonviral delivery systems for gene delivery. Adv Biomed Res. 2012; 1 (1): 27.

9. Yang N. An overview of viral and nonviral delivery systems for microRNA. Int J Pharm Investig. 2015; 5 (4): 179.

10. Nayak S, Herzog RW. Progress and prospects: immune responses to viral vectors. Gene Ther. 2010; 17 (3): 295-304.

11. Qiu J, Kong L, Cao X, Li A, Wei P, Wang L et al. Enhanced Delivery of Therapeutic siRNA into Glioblastoma Cells Using DendrimerEntrapped Gold Nanoparticles Conjugated with $\beta$-Cyclodextrin. Nanomaterials. 2018; 8 (3): 131.

12. Singh Y, Tomar S, Khan S, Meher JG, Pawar VK, Raval K et al. Bridging small interfering RNA with giant therapeutic outcomes using nanometric liposomes. J Control Release. 2015; (220): 36887

13. Leung AK, Tam YY, Cullis PR. Lipid Nanoparticles for Short Interfering RNA Delivery. Adv Genet. 2014; (88): 71-110

14. Nakamura $T$, Yamada $K$, Fujiwara $Y$, Sato $Y$, Harashima $H$. Reducing the Cytotoxicity of Lipid Nanoparticles Associated with a Fusogenic Cationic Lipid in a Natural Killer Cell Line by Introducing a Polycation-Based siRNA Core. Mol Pharm. 2018; 15 (6): 2142-50

15. Jin M, Jin G, Kang L, Chen L, Gao Z, Huang W. Smart polymeric nanoparticles with $\mathrm{pH}$-responsive and PEG-detachable properties

for co-delivering paclitaxel and survivin siRNA to enhance antitumor outcomes. Int J Nanomedicine. 2018; (13): 2405

16. Novobrantseva TI, Borodovsky A, Wong J, Klebanov B, Zafari M, Yucius $\mathrm{K}$ et al. Systemic RNAi-mediated Gene Silencing in Nonhuman Primate and Rodent Myeloid Cells. Mol Ther Nucleic Acids. 2012; (1): e4

17. Kumar V, Qin J, Jiang Y, Duncan RG, Brigham B, Fishman S et al. Shielding of Lipid Nanoparticles for siRNA Delivery: Impact on Physicochemical Properties, Cytokine Induction, and Efficacy. Mol Ther Nucleic Acids. 2014; (3): e210.

18. Alshehri A, Grabowska A, Stolnik S. Pathways of cellular internalisation of liposomes delivered siRNA and effects on siRNA engagement with target mRNA and silencing in cancer cells. Sci Rep. 2018; 8 (1): 3748.

19. Soenen SJ, Hodenius M, De Cuyper M. Magnetoliposomes: versatile innovative nanocolloids for use in biotechnology and biomedicine. Nanomedicine. 2009; 4 (2): 177-91.

20. Dobson J. Magnetic nanoparticles for drug delivery. Drug Dev Res [Internet]. 2006 [cited 2017 Sep 18]; 67(1): 55-60. Available from: http://onlinelibrary.wiley.com/doi/10.1002/ddr.20067/abstract.

21. Zhang JQ, Zhang ZR, Yang H, Tan QY, Qin SR, Qiu XL. Lyophilized paclitaxel magnetoliposomes as a potential drug delivery system for breast carcinoma via parenteral administration: in vitro and in vivo studies. Pharm Res [Internet]. 2005 [cited 2017 Sep 18]; 22 (4): 573-83. Available from: http://www.ncbi.nlm.nih.gov/ pubmed/15846465.

22. Yang L, Wang Z, Ma L, Li A, Xin J, Wei R et al. The Roles of Morphology on the Relaxation Rates of Magnetic Nanoparticles. ACS Nano. 2018; 12 (5): 4605-14.

23. Bronstein LM, Huang X, Retrum J, Schmucker A, Pink M, Stein BD et al. Influence of Iron Oleate Complex Structure on Iron Oxide Nanoparticle Formation. 2007 [cited 2017 Dec 16]; 19 (15): 3624-32. Available from: http://pubs.acs.org/doi/abs/10.1021/ cm062948j.

24. Hai HT, Yang HT, Kura H, Hasegawa D, Ogata $Y$, Takahashi M et al. Size control and characterization of wustite (core)/spinel (shell) nanocubes obtained by decomposition of iron oleate complex. J Colloid Interface Sci [Internet]. 2010; 346 (1): 37-42. Available from: http://dx.doi.org/10.1016/j.jcis.2010.02.025.

25. Jiang S, Eltoukhy A, Love K, Langer R, Anderson D. LipidoidCoated Iron Oxide Nanoparticles for Efficient DNA and siRNA delivery. Nano Lett [Internet]. 2013; 1-6. Available from: citeulike-article-id:12014954\%5Cnhttp://dx.doi.org/10.1021/ nl304287a.

26. Love KT, Mahon KP, Levins CG, Whitehead KA, Querbes W, Dorkin JR et al. Lipid-like materials for low-dose, in vivo gene silencing. Proc Natl Acad Sci. 2010; 107 (5): 1864-9.

27. Mosmann T. Rapid colorimetric assay for cellular growth and 
survival: Application to proliferation and cytotoxicity assays. $J$ Immunol Methods. 1983; 65 (1-2): 55-63.

28. Mamani JB, Costa-Filho AJ, Cornejo DR, Vieira ED, Gamarra LF Synthesis and characterization of magnetite nanoparticles coated with lauric acid. Mater Charact. 2013; (81): 28-36.

29. Nemati Z, Das R, Alonso J, Clements E, Phan MH, Srikanth H. Iron Oxide Nanospheres and Nanocubes for Magnetic Hyperthermia Therapy: A Comparative Study. J Electron Mater [Internet]. 2017 [cited 2017 Dec 16]; 46 (6): 3764-9. Available from: http://link. springer.com/10.1007/s11664-017-5347-6.

30. Cullity BD, Graham CD. Introduction to magnetic materials. 2nd ed. Hoboken, NJ: IEEE/Wiley, 2009; 544 p.

31. Marciello M, Connord V, Veintemillas-Verdaguer S, Vergés MA, Carrey J, Respaud M, et al. Large scale production of biocompatible magnetite nanocrystals with high saturation magnetization values through green aqueous synthesis. J Mater Chem B. 2013; 1 (43): 5995-6004.

32. Verma A, Stellacci F. Effect of Surface Properties on NanoparticleCell Interactions. Small. 2010; 6 (1): 12-21.

33. Adler AF, Leong KW. Emerging links between surface nanotechnology and endocytosis: Impact on nonviral gene delivery. Nano Today. 2010; 5 (6): 553-69.

34. Gupta AK, Gupta M. Cytotoxicity suppression and cellular uptake enhancement of surface modified magnetic nanoparticles. Biomaterials [Internet]. 2005 [cited 2017 Jun 9]; 26 (13): 1565-73.
Available from: http://www.ncbi.nlm.nih.gov/pubmed/15522758.

35. Gupta AK, Curtis AS. Lactoferrin and ceruloplasmin derivatized superparamagnetic iron oxide nanoparticles for targeting cell surface receptors. Biomaterials. 2004; 25 (15): 3029-40.

36. Soenen SJH, Nuytten N, De Meyer SF, De Smedt SC, De Cuyper M. High Intracellular Iron Oxide Nanoparticle Concentrations Affect Cellular Cytoskeleton and Focal Adhesion Kinase-Mediated Signaling. Small. 2010; 6 (7): 832-42.

37. Berry CC. Progress in functionalization of magnetic nanoparticles for applications in biomedicine. J Phys D Appl Phys. 2009; 42 (22): 224003.

38. Zhang J, Ring HL, Hurley KR, Shao Q, Carlson CS, Idiyatullin D et al. Quantification and biodistribution of iron oxide nanoparticles in the primary clearance organs of mice using $\mathrm{T} 1$ contrast for heating. Magn Reson Med [Internet]. 2017 [cited 2017 Dec 22]; 78 (2): 702-12. Available from: http://www.ncbi.nlm.nih.gov/ pubmed/27667655.

39. Bargheer D, Giemsa A, Freund B, Heine M, Waurisch C, Stachowski GM et al. The distribution and degradation of radiolabeled superparamagnetic iron oxide nanoparticles and quantum dots in mice. Beilstein J Nanotechnol. 2015; (6): 111-23.

40. Ruiz A, Hernández Y, Cabal C, González E, Veintemillas-Verdaguer S, Martínez E, et al. Biodistribution and pharmacokinetics of uniform magnetite nanoparticles chemically modified with polyethylene glycol. Nanoscale. 2013; 5 (23): 11400-8. 